\title{
Lusioersily
}

\section{Evaluating conditions for transboundary Marine Spatial Planning: Challenges and opportunities on the island of Ireland}

Flannery, W., O'Hagan, A. M., O'Mahoney, C., Ritchie, H., \& Twomey, S. (2015). Evaluating conditions for transboundary Marine Spatial Planning: Challenges and opportunities on the island of Ireland. Marine Policy, 51, 86-95. https://doi.org/10.1016/j.marpol.2014.07.021

Link to publication record in Ulster University Research Portal

Published in:
Marine Policy

Publication Status:

Published (in print/issue): 01/01/2015

DOI:

10.1016/j.marpol.2014.07.021

Document Version

Author Accepted version

\section{General rights}

Copyright for the publications made accessible via Ulster University's Research Portal is retained by the author(s) and / or other copyright owners and it is a condition of accessing these publications that users recognise and abide by the legal requirements associated with these rights.

\section{Take down policy}

The Research Portal is Ulster University's institutional repository that provides access to Ulster's research outputs. Every effort has been made to ensure that content in the Research Portal does not infringe any person's rights, or applicable UK laws. If you discover content in the Research Portal that you believe breaches copyright or violates any law, please contact pure-support@ulster.ac.uk. 


\title{
Evaluating conditions for transboundary Marine Spatial Planning: Challenges and opportunities on the island of Ireland
}

\author{
Wesley Flannery a,*, Anne Marie O’Hagan ${ }^{\mathrm{b}, 1}$, Cathal O'Mahony ${ }^{\mathrm{c}, 2}$, Heather Ritchie ${ }^{\mathrm{d}, 3}$, \\ Sarah Twomey ${ }^{\mathrm{c}, 2}$ \\ a School of Planning, Architecture and Civil Engineering, Queen's University Belfast, Belfast, Northern Ireland BT9 5AG, United Kingdom \\ ${ }^{\mathrm{b}}$ Hydraulics and Maritime Research Centre, University College Cork, Pouladuff Road, Togher, Cork, Co. Cork, Ireland \\ ' Coastal and Marine Research Centre, Environmental Research Institute, University College Cork, Naval Base, Haulbowline, Cobh, Co. Cork, Ireland \\ ' School of the Built Environment, University of Ulster, Shore Road, Newtownabbey, Co. Antrim, Northern Ireland BT37 0QB, United Kingdom
}

\section{A R T I C L E I N F O}

\section{Article history:}

Received 9 March 2014

Received in revised form

25 July 2014

Accepted 28 July 2014

\section{Keywords:}

Marine Spatial Planning

Transboundary marine planning

International marine governance

Policy convergence

Transnational institutions

\begin{abstract}
A B S T R A C T
Transboundary cooperation is viewed as an essential element of Marine Spatial Planning (MSP). While much of the MSP literature focuses on the need for, and benefits of, transboundary MSP, this paper explores the political and institutional factors that may facilitate the effective transition to such an approach. Drawing on transboundary planning theory and practice, key contextual factors that are likely to expedite the transition to transboundary MSP are reviewed. These include: policy convergence in neighbouring jurisdictions; prior experience of transboundary planning; and good working relations amongst key actors. Based on this review, an assessment of the conditions for transboundary MSP in the adjoining waters of Northern Ireland and the Republic of Ireland is undertaken. A number of recommendations are then advanced for transboundary MSP on the island of Ireland, including, the need to address the role of formal transboundary institutions and the lack of an agreed legal maritime boundary. The paper concludes with some commentary on the political realities of implementing transboundary MSP.
\end{abstract}

(c) 2014 Elsevier Ltd. All rights reserved.

\section{Introduction}

Marine environments accommodate a diverse range of human activities [1,2] which can result in competition for space between different sea users [3-5]; particularly as the values of ocean resources are becoming increasingly apparent [6]. Additionally, an increase in the level and intensity of human activities has the potential to stress the ecological integrity of marine environments $[7,8]$. In response to these issues, attention has focused on the concept of Marine Spatial Planning (MSP) ${ }^{4}$ as a mechanism for reducing user conflict and as a means of sustainably managing the marine environment [9-12]. The adoption of a transboundary approach to MSP is viewed as critical in shared marine areas [13] as many maritime activities, such as shipping, and stresses,

\footnotetext{
* Corresponding author. Tel.: +442890974754.

E-mail addresses: w.flannery@qub.ac.uk (W. Flannery),

a.ohagan@ucc.ie (A.M. O’Hagan), c.omahony@ucc.ie (C. O’Mahony)

h.ritchie@ulster.ac.uk (H. Ritchie), s.twomey@ucc.ie (S. Twomey).

${ }^{1}$ Tel.: +353214250015.

2 Tel.: +35321 4703100 .

${ }^{3}$ Tel.: + 442890366676 .

${ }^{4}$ Also known as Maritime Spatial Planning, Marine Planning and Coastal and Marine Spatial Planning.
}

such as pollution, may straddle jurisdictional borders [14]. Recent marine legislation and policy in, for example, the EU and North America promotes the adoption of transboundary MSP for the effective and sustainable management of shared marine spaces $[12,15]$. Transboundary cooperation is therefore advanced as a necessary component of effective MSP. Transboundary MSP is viewed, inter alia, as a process which allows for greater integration and harmonisation between existing management frameworks to facilitate the implementation of an ecosystem-based approach [14]; the protection of valuable ecosystem services [16]; effective fisheries management [17]; addressing marine pollution issues [18]; the planning of cross-border marine protected areas (MPAs) [8]; and the selection of the most appropriate sites in the region for development [19].

Where MSP has already been undertaken, however, it has generally been nationally oriented. While some cross-border consultation takes place, it is often ad hoc with little or no evidence of joint planning [20]. Transitioning to transboundary MSP will be challenging. It will be difficult, for example, for neighbouring states to effectively cooperate on transboundary planning decisions without each state having explicit efforts on MSP [20]. Furthermore, cooperation is impeded as neighbouring jurisdictions have different MSP timeframes, with some nations having considerably more developed MSP processes than others. 
Some countries in the Baltic Sea, such as Germany, have developed and implemented marine spatial plans, while in others, such as Poland, MSP is still at a very early stage.

Although much of the academic literature focuses on the need for, and the benefits of, transboundary MSP, little research has been conducted on how transboundary MSP may be best advanced between neighbouring jurisdictions or on the political and institutional conditions that can facilitate effective transboundary cooperation. This paper addresses this gap by developing a theoretical framework to explore some of these issues. This framework is then used to evaluate conditions and institutions ${ }^{5}$ that may affect transboundary MSP in the adjoining waters of Northern Ireland (NI) and the Republic of Ireland (ROI). Recommendations are made, based on the analysis, on potential mechanisms for pursuing transnational working for MSP in the marine spaces around the island of Ireland. The paper concludes with some reflections on the challenges of implementing transboundary MSP.

\section{Key enabling factors for transboundary planning}

Transboundary cooperation is viewed as a critical element of sustainable planning and development in border regions. It is not possible to develop an ideal governance framework for transboundary planning initiatives. Transboundary initiatives need to be designed to suit the issue(s) at hand and to fit within the unique context of the region. It is possible, however, to identify contextual factors that are likely to have an impact on the success of transboundary planning initiatives. These include: policy convergence; common conceptualisation of planning issues; joint vision and strategic objectives; shared experience; and existing transboundary institutions.

\subsection{Policy convergence}

The degree of convergence in policy and legislative arrangements across borders is a critical element of successful transboundary planning. The more alike the policy structures and discourses in neighbouring jurisdictions the more probable it is that transboundary planning will succeed [22]. A number of factors influence the degree of policy convergence in neighbouring states. Policy convergence may arise as a result of the harmonising effect of international and supranational actors. For example, the process of 'Europeanisation' has resulted in policy convergence across EU Member States [23].

Policy convergence can also arise from regulatory competition [24]. Regulatory competition may result in jurisdictions contending to be either the most laissez-faire, (the so-called race to the bottom), or the greenest, (the race to the top); with both forms of competition resulting in policy convergence. Globalisation [25], the elimination of international trade barriers [26] and the increased mobility of workers, goods and capital can drive governments to design policies that place a minimal amount of regulatory burden on business organisations [24]. This can result in a 'race to the bottom', wherein jurisdictions compete to reduce the regulatory encumbrance on firms so as to develop a competitive advantage over one another $[27,28]$. This race to the bottom may lead to policy convergence as jurisdictions descend to the level of the most regulatory relaxed amongst them [29]. Conversely, a number of studies support a race to the top theory, wherein jurisdictions compete to be the greenest [30-32].

\footnotetext{
${ }^{5}$ Institutions are understood here as 'relatively stable collections of communicative practices and rules defining appropriate behaviour for specific groups of actors in specific situations' [21].
}

Increased communication also may lead policymakers to emulate policies of other jurisdictions. This type of policy convergence may arise from simple policy learning and the rational use of available experience to justify policy decisions [29,33], the common conceptualisation of issues across jurisdictions [34], the championing of particular governance mechanisms by international groups and norm-driven and legitimacy-oriented considerations [35].

\subsection{Shared experiences, common issues and joint solutions}

The development of transboundary initiatives can be expedited if the actors involved have previous experience in cross-border cooperation, regardless of the policy area, and have developed a sense of mutual understanding and trust $[36,37]$. The identification of common issues and the collaborative formulisation of mutually beneficial solutions can form the underpinning for lasting transboundary planning. Although institutional arrangements may often discourage transboundary planning, it becomes compelling when actors recognise that they have common goals which are more likely to be achieved by working together [38]. The need to address a common crisis or to avail of mutually beneficial opportunities, for example, may encourage actors in neighbouring jurisdictions to engage with one another [38].

Identifying an area requiring collaboration amongst neighbouring jurisdictions is not, however, sufficient to ensure effective transboundary planning. The most effective transboundary initiatives are those that engage in joint learning, fact-finding and analysis of information as a common group [38]. When analysing cooperative, transboundary ecosystem management initiatives across the Canada-US border, Hildebrand et al. [39] found that success relied on participating jurisdictions exploring commonalities and developing a shared set of objectives and action plans to address common issues. These objectives and plans provide the underpinning for joint action, resulting in the resolution of transboundary issues [39]. Developing strategic projects was found to be a useful way of getting participating countries to focus on one or two key issues and was more beneficial than trying to get participants to instigate a broad collaborative campaign [40]. Strategic joint fact-finding among neighbouring jurisdictions injects impetus, political buy-in and participation into the transboundary planning initiative [40]. The use of the initial strategic projects can strengthen confidence in interjurisdictional working relations, eliminate obstacles to collaborative fact-finding and develop capacity among different actors within each nation [41].

\subsection{Existing transboundary institutions}

The existence of a network of well-developed transboundary institutions reduces transaction costs associated with transboundary planning and facilitates cross-border working [42]. These institutions may be formal or informal alliances and include supranational institutions, such as OSPAR (spanning the NorthEast Atlantic), and sub-national institutions, such as the Severn Estuary Partnership (spanning England and Wales). A network of transboundary institutions will mean that the key actors will know each other, they will have experience in cross-border cooperation and may have developed good working relations [42]. Existing institutions may, however, prescribe or limit the course of action that may be taken to address an issue [43]. Furthermore, governance institutions operating in the same geographical area in the marine environment may have an effect on each other's efficacy. This interplay may occur between institutions operating at the same level, (horizontal interplay) or different levels (vertical interplay) and may be positive or negative [44]. For example, Skjaerseth [45] demonstrates that positive interplay 
Table 1

Evaluation of transboundary institutions against Kidd and McGowan's ladder [47].

\begin{tabular}{|c|c|c|}
\hline Kidd and McGowan's ladder & Function of partnership & Transboundary institution \\
\hline Combined constitution & Changing the political order & The Loughs Agency Single Gas and Electricity Market \\
\hline Combined organisation & Changing the institutional order & $\begin{array}{l}\text { The North South Ministerial Council } \\
\text { The British-Irish Council } \\
\text { Invasive Species Ireland }\end{array}$ \\
\hline Agreed joint rules & Shared rule system & \\
\hline Administration sharing & Creating collaborative advantage & \\
\hline Information sharing & Building trust, understanding and capacity & Offshore renewable energy sector \\
\hline
\end{tabular}

between the North Sea Conferences, OSPAR and the EU accelerated decision-making and has facilitated prompter implementation of International North Sea Conference Declarations. Conversely, the implementation of the Eastern Scotian Shelf Integrated Management Initiative was impeded due to negative interplay between it and existing marine resource management institutions [46]. Thus, it is important to understand how the implementation of MSP will affect and be affected by other institutions.

Kidd and McGowan [47] have developed a ladder of transnational partnership that can be applied to evaluate existing transboundary institutions (see Table 1). The ladder uses five 'rungs' to describe the differing categories of partnership working, with informal partnerships at the bottom and more formalised partnerships at the top. The first rung is 'Information Sharing' where the focus is on building trust, understanding and capacity. Here it is envisaged that parties in the partnership may work independently but could be supported by a small resource which might undertake joint exercises such as stakeholder mapping and facilitation of workshops. The next rung is 'Administration Sharing' where participants perceive that there is an advantage in closer collaboration. Actions may be short term and task focussed or may entail longer term relationships. The third rung on the ladder is 'Agreed Joint Rules' which constitutes a shared rules system, whereby stakeholders might establish common procedures, such as agreed protocols for data collection and exchange. The benefits of this are expressed as improved efficiency, consistency and synergy between different aspects of MSP. Moving towards more formal partnership arrangements, the next rung is 'Combined Organisation', which may involve establishing jointly supported research institutes or other formal transnational institutional arrangements. Finally, the highest and most formalised partnership arrangement rung is described as 'Combined Constitution'. Here joint legal agreements may bring a new political order to the management of a particular sea area, which may mean relinquishing power to shared transnational partnership working.

This ladder can be used to assess the nature of existing transboundary institutions and to understand which institutions have developed a sense of common understanding and mutually beneficial relationships.

\section{Key questions for transboundary MSP initiatives}

The foregoing discussion raises a number of interrelated issues to be considered when developing transboundary MSP initiatives. Those seeking to develop transboundary MSP initiatives should consider:

(1) The degree of policy convergence that has occurred amongst neighbouring jurisdictions.

(2) Whether or not neighbouring jurisdictions have compatible conceptualisations of MSP and the issues they wish to address through MSP.
(3) The nature of transboundary relations and how current transboundary institutions might facilitate the development of transboundary MSP.

Following sections address these questions in the context of developing a transboundary MSP process on the island of Ireland. The historical background leading to the current political situation on the island of Ireland is outlined in the context of its influence on contemporary marine planning. Political and institutional arrangements as well as national level marine policy in both jurisdictions are examined. Transboundary institutions within key marine sectors are evaluated in terms of their utility and potential for transboundary MSP. Where a number of initiatives exist for particular sectors (e.g. conservation), those most relevant to the discourse on transboundary MSP have been selected.

\subsection{Historical context and influence on marine planning}

The island of Ireland (Fig. 1) consists of 32 administrative counties. Politically, ROI comprises 26 counties whilst the remaining six counties form NI, which is one of the jurisdictions of the United Kingdom (UK). Historically, the entire island of Ireland was part of the UK. Political sensitivities led the British Government to establish two devolved administrations; this partition occurred with the passing of the Government of Ireland Act 1920 which created parliaments for Southern Ireland (26 counties) and NI (6 counties). Over time, Southern Ireland gradually severed all remaining constitutional links with the UK government and became the ROI. NI is a devolved government within the UK, with the power to legislate and govern non-reserved and non-excepted matters. ${ }^{6}$

The implications of this colourful history for MSP on the island are twofold. First, partition was carried out on the basis of administrative counties, which were originally defined in terms of their constituency boundaries; that is to say, the high water mark. Technically, this meant that ROI could lay claim to the territorial waters around NI, apparent in the former Articles 2 and 3 of the Irish Constitution which stated that the national territory consisted of the whole island of Ireland and that the laws applied only to the 26 counties until such times as reintegration occurred [48]. Following the signing of the Good Friday Agreement (GFA) in 1998, however, the right to such a claim was relinquished when Articles 2 and 3 were amended to state that the Irish nation is a community of individuals with a common identity (not a territory) and that the country cannot be reunited without a majority of the electorate in both jurisdictions deciding in favour of such a move [48]. Second, the signing of the GFA resulted in the establishment of a number of transboundary institutions, including: the North South Ministerial Council (NSMC); the British-Irish Council (BIC); and six North South Implementation Bodies, including: the Food Safety Promotion Board; InterTrade Ireland; the Language Body; the

\footnotetext{
${ }^{6}$ The UK Government and UK Parliament retain responsibility for reserved and excepted matters. Reserved matters are policy areas that may be devolved to Northern Ireland Assembly in future. Excepted matters, such as international relations, are areas that are never expected to be considered for devolution.
} 

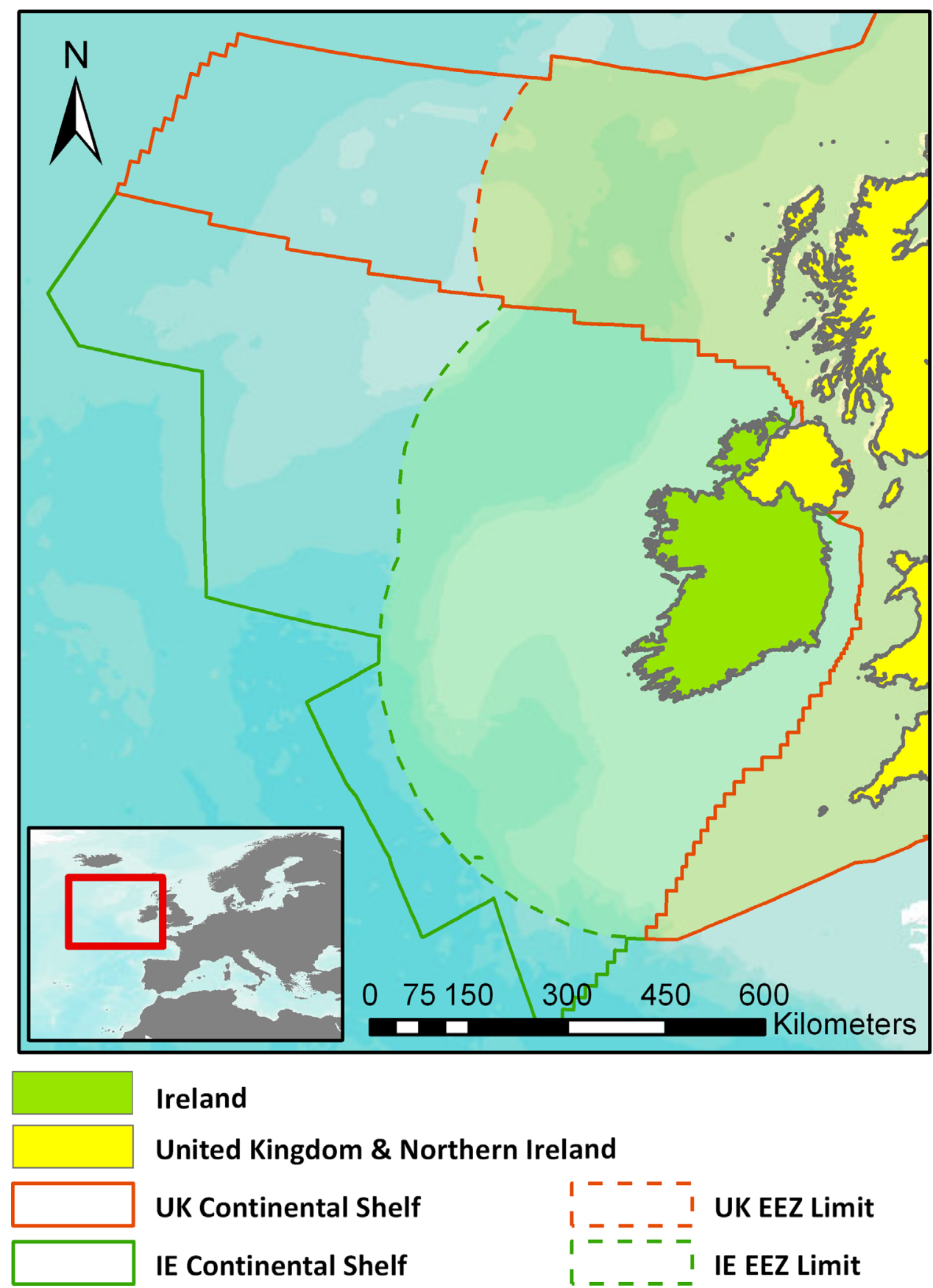

Ireland

\section{United Kingdom \& Northern Ireland}

UK Continental Shelf

IE Continental Shelf

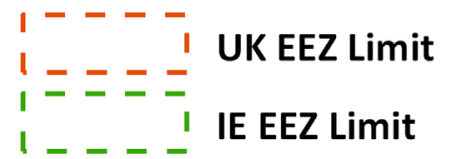

Fig. 1. Map of Republic of Ireland and Northern Ireland.

Special European Union Programmes Body; Waterways Ireland; and the Foyle, Carlingford and Irish Lights Commission (FCILC). With respect to marine functions, the North South Implementation Body of most relevance is the Foyle, Carlingford and Irish Lights Commission. This consists of two agencies: the Loughs Agency; and the Lights Agency. The Loughs Agency has responsibility for the regulation of certain policy areas in Lough Foyle and Carlingford Lough, the border bays separating the two jurisdictions (see Fig. 2). The NSMC, BIC and the Loughs Agency, and how they relate to marine governance, are discussed in Section 3.3.

\subsection{Policy convergence and conceptualisation of MSP}

Due to the harmonisation effect of EU membership, there is a high degree of convergence in the areas of marine policy and legislation on the island of Ireland. A number of EU Directives that have an impact on MSP apply to both jurisdictions (see Table 2). As well as fostering policy convergence, the effective implementation of a number of these Directives requires cooperation amongst neighbouring EU Member States, including, inter allia, the Environmental Impact Assessment Directive, the Strategic Environmental Assessment Directive, the Integrated Pollution Prevention and Control Directive, the Water Framework Directive, the Floods Directive and the Marine Strategy Framework Directive [49].

Both jurisdictions are at different stages of progressing MSP. MSP is at a more advanced stage in NI. The Marine Act (Northern Ireland) 2013 gave practical effect to MSP in NI, within the overall UK framework established through the UK Marine and Coastal Access Act 2009 (the MCCA) and the UK Marine Policy Statement (2010). The UK government and the three devolved administrations (NI Executive, 


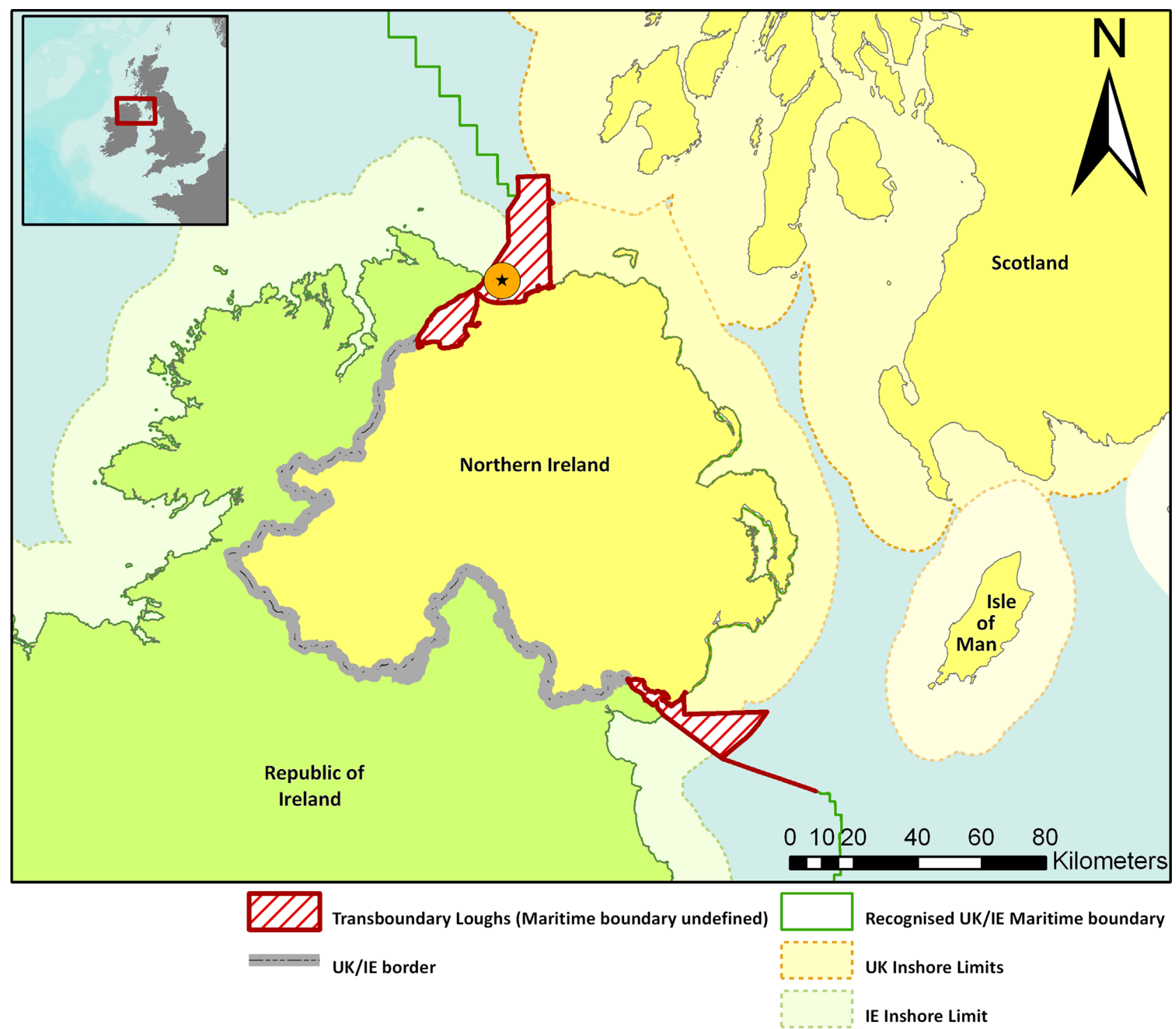

Fig. 2. Maritime boundary areas.

Welsh Assembly Government and the Scottish Government) adopted a set of high level, strategic objectives to ensure consistency in approach across UK waters [50]. In line with the overall UK approach [51], the NI Minister for the Environment highlighted that MSP will reduce the regulatory burden on marine industries and provide greater protection for the marine environment by establishing a strategic system of marine planning in NI's inshore region $(12 \mathrm{~nm}$ limit) [52]. In April 2011, the Department of the Environment Northern Ireland (DOENI) was assigned responsibility for the development of marine plans, marine licensing and consents in the inshore region, and also for developing a marine plan in NI's small offshore region (Fig. 2). DOENI have, however, acquired relatively few new marine regulatory or licensing competencies. This means that NI marine governance remains highly fragmented, largely due to the nature of the devolution settlement for NI.

There are 13 government departments in total that have marine functions within the NI inshore and offshore regions. Directly from the UK government, there is the Department for Energy and Climate Change, Department for Transport, Department of Trade and Industry, the Home Office, Ministry of Defence, Customs and Excise, and the Foreign Office. While the Northern Ireland Executive works closely with the UK Government Departments, there are some activities taking place offshore (beyond
$12 \mathrm{~nm}$ ) that may be considered as reserved matters which operate under the Marine and Coastal Access Act 2009 where the Marine Management Organisation (MMO) is responsible for historic heritage, telecommunications, oil and gas and shipping. From the NI Executive, there are a further six departments with marine functions. These are DOENI, primarily through the Northern Ireland Environment Agency; the Department of Enterprise, Trade and Investment; the Department of Culture, Arts and Leisure; the Department of Agriculture and Rural Development; the Department for Regional Development; and the Department for Social Development has a very small responsibility for a stretch of the River Lagan Impoundment. This fragmentation is somewhat offset by the work of the NI Interdepartmental Marine Co-ordination Group, which facilitates interdepartmental working on such matters as the production of NI's State of the Seas report [53].

In terms of transboundary planning, DOENI, in a briefing to the NI Assembly Environment Committee, stated that they regularly liaise with government departments in ROI on licensing issues, where there is a transboundary effect and that this was incorporated into the Marine Act whereby notification will be given to the corresponding authorities in ROI when a Marine Plan is created. At that time, questions were raised by Committee members over the territorial coverage of the Bill. In 2012, Cave [52] noted that the 
Table 2

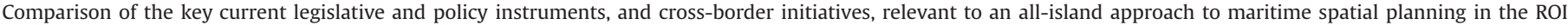
and NI.

\begin{tabular}{|c|c|c|}
\hline & Republic of Ireland & Northern Ireland \\
\hline National Legislation & $\begin{array}{l}\text { Foreshore Acts 1933-2012 } \\
\text { Maritime Area \& Foreshore (Amendment) Bill } 2013\end{array}$ & $\begin{array}{l}\text { UK Marine and Coastal Access Act } 2009 \\
\text { Marine Act (Northern Ireland) } 2013\end{array}$ \\
\hline National Marine Policy, Strategies and Plans & $\begin{array}{l}\text { Harnessing Our Ocean Wealth: An Integrated Marine } \\
\text { Plan for Ireland - Roadmap (launched August 2012) }\end{array}$ & $\begin{array}{l}\text { UK Marine Policy Statement } \\
\text { NI Marine Plan (expected June 2014) } \\
\text { Northern Ireland ICZM Strategy (2006-2026) }\end{array}$ \\
\hline Relevant EU Legislation (not an exhaustive list) & \multicolumn{2}{|c|}{$\begin{array}{l}\text { Marine Strategy Framework Directive (2008/56/EC) } \\
\text { Water Framework Directive (2000/60/EC) } \\
\text { Bathing Water Directive (76/160/EEC) } \\
\text { Birds Directive (2009/147/EC) } \\
\text { Habitats Directive }(92 / 43 / E E C) \\
\text { Strategic Environmental Assessment Directive (2001/42/EC) } \\
\text { Environmental Impact Assessment Directive (85/335/EEC) } \\
\text { Floods Directive (2007/60/EC) } \\
\text { EC REACH Regulation (No. 1907/2006, as amended) and Directive 2006/121/EC } \\
\text { Regulations adopted under the Common Fisheries Policy }\end{array}$} \\
\hline EU Marine Policy and Recommendations & \multicolumn{2}{|c|}{$\begin{array}{l}\text { EU Integrated Maritime Policy } \operatorname{COM}(2007) 575 \text { final } \\
\text { Blue Growth - opportunities for marine and maritime sustainable } \\
\text { growth } \operatorname{COM}(2012) 494 \text { final } \\
\text { Common Fisheries Policy } \\
\text { EU biodiversity strategy to } 2020 \operatorname{COM}(2011) 244 \text { final } \\
\text { Recommendation on Integrated Coastal Zone Management (2002/413/EC) } \\
\text { Roadmap for Maritime Spatial Planning: EU COM(2008) } 791 \text { final Developing } \\
\text { a Maritime Strategy for the Atlantic Ocean Area: } \operatorname{COM}(2011) 782 \text { final }\end{array}$} \\
\hline
\end{tabular}

Bill omitted to include the Loughs Agency specifically and it is not entirely clear how this will impact on the Loughs Agency or how they will be consulted or included in the NI marine plan. However, in the Act, Article 3 stipulates that the Department may enter into arrangements with relevant public authorities, including the Foyle, Carlingford and Irish Lights Commission, to promote the effective co-ordination of management functions in the Northern Ireland inshore region. However, the role of the Loughs Agency in implementing marine plans remains to be defined.

In the ROI, MSP is less developed. In 2014, the government appointed the Department of Environment, Community and Local Government and the Marine Institute to lead MSP. However, MSP has been under consideration in ROI for a number of years and will form part of a mix of marine policy actions. For example, an InterDepartmental Marine Coordination Group prepared 'Harnessing Our Ocean Wealth [HOOW] - An Integrated Marine Plan for Ireland', in 2012 [54]. This group is chaired by the Minister for Agriculture, Food and the Marine and consists of Assistant Secretaries from the government departments with marine-related functions, including: Department of Agriculture, Food and the Marine; Department of the Taoiseach ${ }^{7}$; Department of Defence; Department of Communications, Energy and Natural Resources; Department of Arts, Heritage and the Gaeltacht; Department of Environment, Community and Local Government; Department of Jobs, Enterprise and Innovation; Department of Public Expenditure and Reform; and the Department of Transport, Tourism and Sport. The Attorney General's Office and the Marine Institute (national marine research agency for ROI) also participate. One stated key action of this plan is the development of an appropriate MSP framework for Ireland within which the scope and objectives of an overarching national Marine Spatial Plan will be defined' which will happen in the short to medium term [54]. As this planning framework has yet to be published, it is appropriate to analyse HOOW to understand the likely function and form of MSP in ROI.

\footnotetext{
${ }^{7}$ The ROI equivalent of the Prime Minister.
}

The goals and key actions set out in HOOW are in line with the EU's Integrated Maritime Policy and focuses primarily on increasing marine development opportunities and streamlining the regulatory system so that it is more 'business friendly'. As MSP is being developed by the same government that instigated the HOOW initiative, it is likely that its function will also have a development focus. Although the plan acknowledges the need for healthy ecosystems, it is primarily focused on developing the maritime economy. For example, the strategies to achieve the goal of healthy ecosystems do not contain any commitment to establish MPAs.

In terms of the form of MSP that will be developed, HOOW advocates that a future MSP framework should develop an overarching national marine spatial plan. This plan would provide the governance structure and outline for national, regional and local planning of ROI's marine environment. This suggests that a nested plan approach to MSP may be implemented in ROI, with local and regional marine plans nested within a national strategic plan.

In terms of transboundary planning, HOOW emphasises the importance of international and ROI/NI cooperation. HOOW describes ROI/NI cooperation in the marine area as "traditionally strong'. In relation to ROI/NI cooperation an action within HOOW specifies that fostering a ROI/NI approach in developing/enabling the marine sector through existing structures and bodies will continue as an 'on-going' activity through 'appropriate departments and agencies' [54]. However, as will be discussed below, marine governance does not feature as a major area of discussion in formal transboundary institutions.

\subsection{Existing transboundary institutions on the island of Ireland}

This section examines existing institutions relevant to transboundary MSP on the island of Ireland, including: institutions established under the GFA; and institutions within two key marine sectors, energy and conservation. These policy areas were selected for analysis as they represent important sectors of activity within ROI's [55,56] and NI's marine economies and policy, and are likely to feature in any MSP process. 


\subsubsection{GFA institutions}

The signing of the GFA resulted in the establishment of the NSMC, the BIC and six North South Implementation Bodies, including the Foyle, Carlingford and Irish Lights Commission, which is comprised of the Loughs Agency and the Lights Agency. The role of the NSMC is to develop consultation, co-operation and action within the island of Ireland on matters of mutual interest to both jurisdictions and corresponds to Kidd and McGowan's [47] description of a 'Combined Organisation'. The GFA identified 12 policy areas for cooperation and implementation under the aegis of the NSMC. Cooperation in these areas is to be advanced through two mechanisms: (a) by means of the North South Implementation Bodies; and (b) by existing mechanisms in each jurisdiction separately. The areas of cooperation not covered by the implementation bodies include Agriculture, Education, Environment, Health, Tourism, and Transport. The NSMC meets regularly in relation to each of the 12 Sectors. At these sectoral meetings of the NSMC, the Irish Government is represented by the Minister or the Minister of State responsible for that sector, and the Northern Ireland Executive is represented by two Ministers nominated by the First Minister and deputy First Minister on a crosscommunity $^{8}$ basis, one normally being the Minister with responsibility for that sector. At the moment, the minster responsible for the marine in ROI, the Minster for Agriculture, Food and Marine, attends the Agriculture sectoral meetings, while the minster responsible for marine in NI, the Minster for the Environment, attends the Environment sectoral meetings. This means that the highly specific and sectoral nature of NSMC meetings limits the potential for marine governance to be discussed at NSMC meetings.

At a supranational level, the role of the BIC is to promote positive, practical relationships among its members, which are the British and Irish Governments, the devolved administrations of Northern Ireland, Scotland and Wales, and Jersey, Guernsey and the Isle of Man. The members of the British-Irish Council cooperate on bringing work forward in areas of mutual interest, including the environment. The BIC would occupy the 'Combined Organisation' rung of Kidd and McGowan's [47] ladder. In relation to the environment work area, in the past the Council has discussed how the Council could help deliver the objectives set out in the OSPAR Convention, the European Marine Strategy, and those relevant to sustainable development and biodiversity. Most recently in June 2014 the Council met in Cork in the ROI to discuss cooperation in relation to growing the marine renewable energy sector.

Following the signature of the GFA in 1998, the functions relating to the regulation of both Lough Foyle and Carlingford Lough were transferred to the Loughs Agency. The role of the Agency is to place environmental issues at the heart of international, national and local decision-making. Specific functions of the Loughs Agency include the promotion of development in Lough Foyle and Carlingford Lough for commercial and recreational purposes in respect of marine, fishery and aquaculture matters. The Loughs Agency has specific functions in terms of the transboundary management of fisheries and aquaculture development in these bays. Enabling cross-border functions in relation to aquaculture, joint legislation was introduced in 2007. The Foyle and Carlingford Fisheries (Northern Ireland) Order 2007 and the Foyle and Carlingford Fisheries Act, 2007 (ROI) provided a new regulatory system for aquaculture in the Foyle and Carlingford areas and for the transfer of existing licensing powers in the Foyle

\footnotetext{
${ }^{8}$ The GFA introduced a consociational model of democracy wherein power is shared between NI's two major communities: Unionists (an ideology which favours the continuation of some form of political union with the UK); and Nationalists (an ideology that generally refers to support for NI joining ROI).
}

and Carlingford areas from the two sponsoring government Departments (Department of Agriculture and Rural Development in NI and Department of Communications, Marine and Natural Resources in ROI) to the FCILC. The Loughs Agency would, thus, occupy the highest rung in Kidd and McGowan's [47] ladder 'Combined Constitution' and would, on the surface, appear to have changed the political order in terms of how these sea areas are governed. However, in minutes of the Foyle and Carlingford Area Advisory Forum (September 2008) it was noted that no licences are in operation in Lough Foyle as none have been granted due to issues relating to jurisdiction. The Loughs Agency Business Plan 2013 states that 'the Agency and the DCENR officials met with DAFM officials several times during 2012 with a view to finalising the Management Agreement for the Loughs, which will enable the Agency to introduce the licensing of aquaculture in Lough Foyle. This Agreement remains outstanding but it is hoped that an agreement will be secured in 2013' [57].

\subsubsection{Energy}

The marine renewable energy (offshore wind, wave and tidal) sector provides significant potential development and employment opportunities in both jurisdictions. There is, however, little evidence of transboundary cooperation in relation to planning and cooperation in this sector could be classed, at best, as Information Sharing. The preparation of offshore renewable energy development plans in both jurisdictions [58,59], for example, were subject to separate Strategic Environmental Assessments (SEAs) prepared by the same consultancy $[60,61]$. Following completion of the SEA of the Northern Ireland Plan, The Crown Estate launched the process for the NI Offshore Renewable Energy Leasing Round in March 2011. In ROI, the SEA was carried out in parallel with the development of the Offshore Renewable Energy Development Plan, though the plan itself was published years later in 2014 [59]. Limited consideration is given in either plan to how renewable energy development in shared marine spaces may be best advanced. This can be attributed to the fact that there has been no formal, legal delimitation of the maritime boundaries in the border bays between NI and ROI. In light of this ROI and UK governments adopted and signed a Memorandum of Understanding in 2011. This states that they 'may each arrange for the lease of the seabed to facilitate the development of offshore renewable energy installations, and for the licensing of construction and operation of such installations, up to their respective sides of the two lines constituted by the lists of coordinates and depicted on illustrative maps' (Fig. 2). It is critical to note that this is a political commitment between the two governments and does not constitute a legal agreement on the boundaries.

In the past, the absence of definitive maritime boundaries and the lack of a spirit of cooperation between ROI and NI in relation to renewable energy development also led to confusion over competencies and, at a more practical level, withdrawal of a substantial offshore wind development on the north coast of NI. The Tunnes Plateau Offshore Wind Farm was proposed by a consortium, which included B9 Energy Offshore Developments and Powergen. The consortium applied to The Crown Estate for a licence to develop an offshore wind farm of up to 85 turbines, with a nominal capacity of 150-250 MW. In June 2002, The Crown Estate, believing it was the owner of the proposed site on the seabed, granted a licence to the developer. This was met with opposition from the ROI Government who claimed that it owned part of the site and consequently the project would, therefore, need its approval [62]. In October 2002, NI confirmed the possibility that part of the Tunnes Plateau could fall within 'Irish' jurisdiction [62]. In September 2004, Powergen withdrew from the consortium, effectively ending any possibility of the project being developed. 
The above situation can be contrasted with the electricity sector, wherein transboundary planning would occupy the 'Combined Constitution' of Kidd and McGowan's [47] ladder. Cooperation between ROI and NI on electricity matters happens under the auspices of a Joint Steering Group established in July 2003. This comprises senior officials from the Department of Communications, Energy and Natural Resources (ROI) and NI Department of Enterprise, Trade and Investment and the offices of the two Regulatory Authorities: Commission for Energy Regulation, in ROI and the Northern Ireland Authority for Utility Regulation, in NI. A joint decision, taken in 2004, aimed to create a single market for natural gas and electricity on the island of Ireland. This created a gross mandatory pool market, into which all electricity generated on or imported onto the island of Ireland must be sold, and from which all wholesale electricity for consumption on or export from the island of Ireland must be purchased. Legislation was subsequently enacted in both jurisdictions to give effect to this regime. This has implications for MSP in that the operation of a single market facilitates associated development and infrastructure planning.

\subsubsection{Conservation}

Considering the island of Ireland comprises a single biogeographical unit, there exists potential for key species of conservation concern and interest to move between the two jurisdictions. As habitats of one may well support species health and biodiversity in the other, the benefits of cross-border working and combining of resources for the purposes of conservation are apparent. For example, in order to combat the introduction and spread of invasive species on the island as a whole, a transboundary task force, Invasive Species Ireland, was set up as a joint body between the NI Environment Agency and the National Parks and Wildlife Service (ROI). Invasive Species Ireland is considered a coordination body with a remit to: provide advice and resources for stakeholders; carrying out risk assessment, policy development; undertake education and awareness activities, research; and develop invasive species action plans. Examples of actions undertaken by Invasive Species Ireland to date include the initiation of 14 projects focusing on different aspects of invasive species (e.g. policy, monitoring, education) and the organisation of an annual forum (2007 to present) open to all stakeholders on the island with an interest in invasive species management and control. The activities of Invasive Species Ireland extend to terrestrial and marine environments; for the latter, Invasive Species Ireland have detailed species of established and potential threat and have contributed to work undertaken to assess the risk and spread of non-indigenous species in the waters of UK and ROI [63]. Plans are also underway to harmonise invasive species strategies for NI and the ROI.

The commitment by both jurisdictions to jointly fund the work of Invasive Species Ireland and the scale of their activities to date implies they fulfil the criteria for 'Combined Organisation' [47], whereby formal actions and cross-institutional working are evident.

\section{Developing transboundary MSP on island of Ireland}

The Tunnes Plateau example highlights the cost of not having an integrated transboundary planning regime in place, where MSP can help to support a strategy for sustainable marine resource management as well as economic growth from shared marine resources. Thus, there is benefit in neighbouring jurisdictions examining mechanisms to advance MSP in adjoining waters in a co-ordinated and cohesive manner which is certainly the case for the island of Ireland, where the utilisation of the marine environment and its resources is now a political and economic priority for both the ROI and NI. Both jurisdictions are, however, largely progressing MSP separately from one another. Although there appears to be procedural requirements for transboundary consultation on draft plans and documents, little or no consideration is being given to joint planning.

The evaluation of the existing policy and institutional conditions in this paper indicates that there is a basis for transboundary MSP. Due to EU membership, there is a high degree of policy convergence in relevant areas between the two jurisdictions. Furthermore, both jurisdictions, including the UK Government, will be expected to co-operate to fulfil the commitments under various EU Directives. Both jurisdictions also have compatible conceptualisations of MSP, where it is viewed as an economic development tool, aimed at promoting development opportunities in their respective marine areas. Finally, there are already a number of joint planning institutions on which transboundary MSP between ROI and NI could build upon. The work of Invasive Species Ireland and the Electricity Joint Steering Group, for example, demonstrate the valuable role these institutions provide in terms of transboundary cooperation and joint planning.

This evaluation also illustrates a number of complex policy, political and institutional issues that will need to be addressed in order to advance transboundary MSP on the island of Ireland. For example, MSP is at a considerably more advanced stage in NI than in ROI. This may create an issue when attempting to develop actions or plans for border areas. While our analysis illustrates that there are a number of transboundary institutions that could play a role in advancing transboundary MSP, the role of the Loughs Agency, a highly formalised transboundary marine institution, which is already engaged in cross-border marine affairs, in progressing MSP in either jurisdiction remains unclear. While it is not feasible to turn the Loughs Agency into the MSP authority for the island, it is obvious that they must be involved in the discussions occurring in each jurisdiction, due to their remit, and dedicated responsibilities, for two large shared bays. Finally, it is also clear from this analysis that marine governance is not a priority area for the NSMC and that the most appropriate supranational body through which to advance transboundary MSP may be the BIC.

A number of steps should be taken to advance transboundary MSP on the island of Ireland. First, local area marine plans should be developed for shared bays. This could be led by the Loughs Agency to ensure positive institutional interplay between its remit and the resulting local plans. This suggestion may be easier to accommodate within the form of MSP being developed in ROI, who appear to be adopting a nested plan approach to MSP. The development of joint plans for these bays should be seen as a strategic project aimed at facilitating joint learning and fact finding and further enhancing inter-jurisdictional working relations. Second, joint meetings of the respective marine coordination groups should be held as the institutional structures within one jurisdiction do not readily map onto those in the other, and individuals within agencies tasked with regulatory responsibility for MSP in each jurisdiction will benefit from an understanding of the institutional arrangements of their counterparts in order to deliver effective transboundary marine planning. Third, owing to the fact that some marine-related functions in NI waters remain within the remit of UK government departments, advancing transnational MSP may be best achieved through trilateral, rather than bilateral, cooperation and the role of the BIC should be explored in this manner. Finally, there is an obvious need to address the issue of maritime boundaries so as to allow the Loughs Agency to function as prescribed and to create certainty for regulators, developers and all marine users. 


\section{Conclusion}

It is clear that the degree to which government departments and agencies, marine sectors and coastal communities from neighbouring jurisdictions have historically engaged in cooperative planning is likely to impact on the capacity of neighbouring jurisdictions to develop transboundary MSP systems. The existence of good transboundary working relations amongst key marine actors will benefit transboundary MSP projects. Conversely, poor or antagonistic relations add an extra impediment to be overcome. Planning, however, is no longer the province of government departments and agencies alone. It is increasingly recognised that effective planning cannot be achieved through government intervention only and that the critical role of sectoral and community stakeholders must be recognised. The emphasis on multilateral agreements among states is often inappropriate and may be counterproductive as it diverts focus away from promising strategies that involve collective collaborative governance arrangements that include sub-national and non-state actors [64]. Thus, transboundary MSP should not be concerned solely with aligning government action in neighbouring jurisdictions but should also look at how sub-national actors are cooperating to address issues that may be germane to transboundary MSP. There is value, therefore, in exploring how both national and sub-national institutions could aid the implementation of transboundary MSP.

Whilst it may be easier to obtain agreement on strategic, transnational marine spatial plans, this form of planning, on its own, may not be sufficient to resolve transboundary conflicts. For example, though it was possible for both governments on the island of Ireland to develop strategic plans to develop a Single Electricity Market it was not possible for them to resolve conflict surrounding the Tunnes Plateau development. Therefore, it may be necessary to consider the development of specific local area marine plans for border areas. This is already happening, to an extent, in relation to river management through three International River Basin Districts as part of implementation of the Water Framework Directive.

\section{Acknowledgements}

The authors thank Rory Scarrott of the Coastal and Marine Research Centre (CMRC) in University College Cork for the production of Figs. 1 and 2. The contribution of Anne Marie O'Hagan is based upon works supported by Science Foundation Ireland (SFI) under the Charles Parsons Award for Ocean Energy Research (Grant number 06/CP/E003).

\section{References}

[1] Weinstein MP, Baird RC, Conover DO, Gross M, Keulartz J, Loomis DK, et al. Managing coastal resources in the 21st century. Front Ecol Environ 2007;5:43-8

[2] Martínez ML, Intralawan A, Vázquez G, Pérez-Maqueo O, Sutton P, Landgrave R. The coasts of our world: ecological, economic and social importance. Ecol Econ 2007;63:254-72.

[3] Gilliland PM, Laffoley D. Key elements and steps in the process of developing ecosystem-based marine spatial planning. Mar Policy 2008;32:787-96.

[4] Douvere F, Ehler CN. New perspectives on sea use management: initial findings from European experience with marine spatial planning. J Environ Manag 2009:90:77-88.

[5] Hull AD. Managing competition for marine space using the tools of planning in the UK. Plan Pract Res 2013;28:503-26.

[6] Beaudoin Y, Pendleton L (editors). Why value the oceans - a discussion paper. Geneva: TEEB; 2012.

[7] Salomidi M, Katsanevakis S, Borja A, Braeckman U, Damalas D, Galparsoro I, et al. Assessment of goods and services, vulnerability, and conservation status of European seabed biotopes: a stepping stone towards ecosystem-based marine spatial management. Mediterr Mar Sci 2012:13.
[8] Calado H, Ng K, Johnson D, Sousa L, Phillips M, Alves F. Marine spatial planning: lessons learned from the Portuguese debate. Mar Policy 2010;34:1341-9.

[9] Douvere F. The importance of marine spatial planning in advancing ecosystem-based sea use management. Mar Policy 2008;32:762-71.

[10] Ritchie H, Ellis G. A system that works for the sea? Exploring stakeholder engagement in marine spatial planning J Environ Plan Manag 2010;53:701-23.

[11] Burns K. Global perspectives on how marine spatial planning can contribute to the management of Ireland's ocean resources. Borderl J Spat Plan Irel $2012 ; 2: 73-85$.

[12] Flannery W, Ó Cinnéide M. Stakeholder participation in marine spatial planning: lessons from the channel islands national marine sanctuary. Soc Nat Resour 2012;25:727-42.

[13] Drankier P. Embedding maritime spatial planning in national legal frameworks. J Environ Policy Plan 2012;14:7-27.

[14] Backer H. Transboundary maritime spatial planning: a Baltic Sea perspective. J Coast Conserv 2011;15:279-89.

[15] Flannery W, Ó. Cinnéide M. A roadmap for marine spatial planning: a critical examination of the European Commission's guiding principles based on their application in the Clyde MSP Pilot Project. Mar Policy 2012;36:265-71.

[16] Mackenzie CL, Bell MC, Birchenough SNR, Culloty SC, Sanderson WG, Whiteley NM, et al. Future socio-economic and environmental sustainability of the Irish Sea requires a multi-disciplinary approach with industry and research collaboration, and cross-border partnership. Ocean Coast Manag 2013;85:1-6.

[17] Degnbol D, Wilson DC. Spatial planning on the North Sea: a case of cross-scale linkages. Mar Policy 2008;32:189-200.

[18] Duck RW. Marine spatial planning: managing a dynamic environment. J Environ Policy Plan 2012;14:67-79.

[19] Maes F. The international legal framework for marine spatial planning. Mar Policy 2008;32:797-810.

[20] Payne I, Tindall C, Hodgson S, Harris C. Comparative analysis of Maritime Spatial Planning (MSP) regimes, barriers and obstacles, good practices and national policy recommendations. Seaenergy 2020; 2011.

[21] Risse T. Constructivism and international institutions. toward conversations across paradigms. In: Katznelson I, Milner H, editors. Political science: state of the discipline. Washington, DC: American Political Science Association; 2002. p. 597-623.

[22] Wiering M, Verwijmeren J. Limits and borders: stages of transboundary water management. J Borderl Stud 2012;27:257-72.

[23] Perkins R, Neumayer E. Europeanisation and the uneven convergence of environmental policy: explaining the geography of EMAS. Environ Plan C 2004;22:881-97.

[24] Holzinger K, Knill C. Causes and conditions of cross-national policy convergence. J Eur Public Policy 2005;12:775-96.

[25] Drezner DW. Globalization and policy convergence. Int Stud Rev 2001;3: $53-78$.

[26] Simmons BA, Elkins Z. The globalization of liberalization: policy diffusion in the international political economy. Am Polit Sci Rev 2004;98:171-89.

[27] Hoberg G. Globalization and policy convergence: symposium overview. J Comp Policy Anal Res Pract 2001;3:127-32.

[28] Keohane RO, Nye JS. Globalization: what's new? What's Not? (and so what?) Foreign Policy 2000:104-19.

[29] Holzinger K, Knill C. Competition, cooperation and communication: a theoretical analysis of different sources of environmental policy convergence and their interaction. Vienna: Institute for Advanced Studies; 2005.

[30] Hoberg G. Globalization and policy convergence. J Comp Policy Anal Res Pract 2001;3:127-241.

[31] Vogel D. Trading up and governing across: transnational governance and environmental protection. J Eur Public Policy 1997;4:556-71.

[32] Perkins R, Neumayer E. Does the "California effect" operate across borders? Trading- and investing-up in automobile emission standards J Eur Public Policy 2012;19:217-37.

[33] Dolowitz DP, Marsh D. Learning from abroad: the role of policy transfer in contemporary policy-making. Governance 2000;13:5-23.

[34] Haas PM. Do regimes matter? Epistemic communities and Mediterranean pollution control Int Organ 1989;43:377-403.

[35] Busch P, Jörgens H. The international sources of policy convergence: explaining the spread of environmental policy innovations. J Eur Public Policy 2005; $12: 860-84$.

[36] Deppisch S. Social capital and other main influences on governance processes in cross-border micro-regions. Cross-border governance and sustainable spatial development. Berlin Heidelberg: Springer; 2008; 67-83.

[37] Head BW. Assessing network-based collaborations effectiveness for whom? Public Manag Rev 2008;10:733-49.

[38] Erg B, Vasilijević M, McKinney M. Initiating effective transboundary conservation: A practitioner's guideline based on the experience from the Dinaric Arc. Gland, Switzerland and Belgrade, Serbia: IUCN Programme Office for SouthEastern Europe; 2012.

[39] Hildebrand LP, Pebbles V, Fraser DA. Cooperative ecosystem management across the Canada-US border: approaches and experiences of transboundary programs in the Gulf of Maine, Great Lakes and Georgia Basin/Puget Sound. Ocean Coast Manag 2002;45:421-57.

[40] Uitto JI, Duda AM. Management of transboundary water resources: lessons from international cooperation for conflict prevention. Geogr J 2002;168:365-78.

[41] Bewers JM, Uitto JI. International waters program study: evaluation report\#1$01 ; 2001$. 
[42] Leibenath M, Blum A, Stutzriemer S. Transboundary cooperation in establishing ecological networks: the case of Germany's external borders. Landsc Urban Plan 2010;94:84-93.

[43] Blatter J. Lessons from Lake Constance: ideas, institutions, and advocacy coalitions. In: Ingram HM, Blatter J, editors. Reflections on water: new approaches to transboundary conflicts and cooperation. Cambridge, MA: MIT Press; 2001. p. 89-122.

[44] Gehring T, Oberthur S. Interplay: exploring institutional interaction. In: Young OR, King LA, Schroeder $\mathrm{H}$, editors. Institutions and environmental change: principal findings, applications, and research frontiers. Cambridge, MA: MIT; 2008. p. 187-224.

[45] Skjaerseth JB. Protecting the Norteast Atalantic: one problem, three institutions. In: Oberthur S, Gehring T, editors. Institutional interaction in global environmental governance: synergy and conflict among international and EU policies. Cambridge, MA: MIT Press; 2006. p. 103-26.

[46] Flannery W, Ó Cinnéide M. Deriving lessons relating to marine spatia planning from Canada's Eastern Scotian Shelf integrated management initiative. J Environ Policy Plan 2012;14:97-117.

[47] Kidd S, McGowan L. Constructing a ladder of transnational partnership working in support of marine spatial planning: thoughts from the Irish Sea. J Environ Manag 2013;126:63-71.

[48] Government of Ireland. Bunreacht na hÉireann; 1937.

[49] Qiu W, Jones PJS. The emerging policy landscape for marine spatial planning in Europe. Mar Policy 2013;39:182-90.

[50] Fletcher S, Jefferson R, Glegg G, Rodwell L, Dodds W. England's evolving marine and coastal governance framework. Mar Policy 2014;45:261-8.

[51] Ritchie H. Understanding emerging discourses of marine spatial planning in the UK. Land Use Policy 2014;38:666-75. http://dx.doi.org/10.1016/j. landusepol.2014.01.009.

[52] Cave S. Northern Ireland marine bill, research and information service paper bill, paper 110/12. Belfast: Northern Ireland Assembly; 2012.

[53] Gibson CE. Northern Ireland State of the Seas report. Belfast: NIEA; n.d.
[54] Government of Ireland/Marine Coordination Group. Harnessing our ocean wealth - an integrated marine plan for Ireland roadmap: new ways, new approaches, new thinking. Dublin, Ireland: Government of Ireland; 2012.

[55] Kopke K, O'Mahony C. Preparedness of key coastal and marine sectors in Ireland to adapt to climate change. Mar Policy 2011;35:800-9.

[56] Morrissey K, O'Donoghue C. The role of the marine sector in the Irish national economy: an input-output analysis. Mar Policy 2013;37:230-8.

[57] The Loughs Agency. The Loughs Agency business plan. Derry/Londonderry: The Loughs Agency; 2013.

[58] Department of Enterprise, Trade and Investment (DETI). Offshore renewable energy strategic action plan 2012-2020. Belfast, Northern Ireland: DETI; March 2012. Available at: 〈http://www.detini.gov.uk/ni_offshore_renewable energy_strategic_action_plan_2012-2020_march_2012_.pdf).

[59] Department of Communications, Energy \& Natural Resources. Offshore Renewable Energy Development Plan. Dublin: Department of Communications, Energy \& Natural Resources; 2014. Available at: 〈http://www.dcenr.gov. ie/NR/rdonlyres/836DD5D9-7152-4D76-9DA0-81090633F0E0/0/ 20140204DCENROffshoreRenewableEnergyDevelopmentPlan.pdf $\rangle$.

[60] AECOM and Metoc. Offshore wind and marine renewable energy in Northern Ireland Strategic Environmental Assessment (SEA) Non-Technical Summary (NTS). Cheshire, England: AECOM Limited; 2009.

[61] AECOM, Metoc, CMRC and SEAI. Offshore Renewable Energy Development Plan (OREDP) for Ireland Strategic Environmental Assessment (SEA) Volume 1: Non-Technical Summary (NTS). Cheshire, England: AECOM Limited; 2010.

[62] Ellis G, Barry J, Robinson C. Many ways to say "no", different ways to say "yes": applying Q-Methodology to understand public acceptance of wind farm proposals. J Environ Plan Manag 2007;50:517-51.

[63] Pearce F, Peeler E, Stebbing P. Modelling the risk of the introduction and spread of non-indigenous species in the UK and Ireland. London: DEFRA; 2012.

[64] Karkkainen B. Marine ecosystem management \& (and) a post-sovereign transboundary governance. San Diego Int Law J 2004;6:113. 